\title{
Seedling root growth of six broadleaved tree species grown in competition with grass under irrigated nursery conditions
}

\author{
Ralph HARMER*, Malcolm ROBERTSON \\ Forest Research, Alice Holt Lodge, Wrecclesham, Farnham, Surrey GU10 4LH, UK
}

(Received 24 June 2002; accepted 10 March 2003)

\begin{abstract}
Pre-treated seeds of ash, silver birch, field maple, hawthorn, rowan and sycamore were sown into open nursery beds half of which were then over-sown with grass seed. After germination most species were harvested at approximately weekly intervals. Height, dry weights, lengths of roots, and numbers of lateral roots and root tips of tree seedlings were assessed. Overall, competition with grass had little effect on seedling size but appeared to reduce development of the lateral root system. However, results were very variable both within and between species, and differences observed were often only indicative and not statistically significant. Competition tended to increase allocation of biomass to roots and the length of the tap-root, but reduced total length of the root system. In general, on a length basis, competition with grass had no effect on the number of 1st order laterals on the tap-root, but the total number of root tips on the root system declined. The response to competition varied with species but differences could not be related simply to competitive ability. The small effects of grass competition may be related to the short duration of the experiment and the irrigation regime used.
\end{abstract}

grass / competition / root / seedling / tree

Résumé - Croissance racinaire de semis de six essences feuillues se développant en concurrence avec des graminées en pépinière irriguée. Des graines prétraitées de frêne, bouleau verruqueux, érable champêtre, aubépine monogyne, sorbier des oiseleurs et d'érable sycomore ont été semées sur des planches de pépinières, à ciel ouvert, puis sur la moitié d'entre elles on a effectué un semis supplémentaire de graines de graminées. Après germination, sur la plupart des espèces, on a procédé à des prélèvements hebdomadaires. Les variables objets de mesures et observations sur les semis étaient : la hauteur, les poids secs, les longueurs de racines, le nombre de racines latérales et des apex racinaires. D'une manière générale, la concurrence des graminées a peu d'effet sur la taille des semis mais semble réduire le développement du système racinaire latéral. Cependant, les résultats varient énormément aux niveaux intra et interspécifiques. Les différences observées indiquent souvent et seulement des tendances sans être statistiquement significatives. La concurrence tend à accroître la proportion de biomasse affectée aux racines ainsi que la longueur du pivot. Mais elle réduit la longueur totale du système racinaire. En général, la concurrence des graminées n'affecte pas le nombre de racines latérales du premier ordre, mais réduit le nombre total d'apex du système racinaire. Les effets de la concurrence varient selon les espèces sans qu'il soit possible de les relier de manière simple à une aptitude à la compétition. La faible importance de l'action de la concurrence est peut-être due à la courte durée de l'expérimentation et au régime d'irrigation mis en œuvre.

herbe / compétition / racine / semis / arbre

\section{INTRODUCTION}

Numerous studies have shown the adverse effects that the ground flora can have on the survival and growth of tree seedlings [7, 9, 24]. Successful methods to counter these effects have been developed and if these are applied properly they can improve the establishment of trees and woodland [9, 33, 34]. In forest conditions these methods often rely on the use of herbicides, but there is a general desire to reduce their use and on some sites they may become unacceptable. In Great Britain the use of secondary succession to create new woodlands, or the restocking of established woodlands by natural regeneration are becoming more popular, but these methods are much less predictable than the well-established, methods of plantation for- estry $[14,15]$. Vegetation management to enhance woodland establishment whilst using these new methods can be difficult, particularly the control of perennial, dicotyledonous weeds amongst broadleaved tree seedlings. Although there is broad, general knowledge about the ability of British forest tree species to establish under different conditions little is known in detail about interactions between the ground flora and tree seedlings. In many situations it is difficult to predict how many trees of what species will become established.

Tree species differ in their ability to establish in competitive conditions, reasons for this are not always clear but may depend on characteristics such as the quality of the site, the time of arrival and the nature of the competing vegetation [3, 23]. Competition occurs both above and below ground; whilst

\footnotetext{
*Corresponding author: ralph.harmer@ forestry.gsi.gov.uk
} 
Table I. Pre-treatments, sowing depth of seeds and date of 1st harvest for each species.

\begin{tabular}{|c|c|c|c|c|}
\hline Species & Common name & Pre-treatment & Depth & Date \\
\hline Acer campestre L. & Field Maple & $\begin{array}{l}4-8 \mathrm{w} \text { at } 15-20^{\circ} \mathrm{C} \text {, } \\
\text { then } 24 \mathrm{w} \text { at } 1-5^{\circ} \mathrm{C}\end{array}$ & 20 & 04-06 \\
\hline A. pseudoplatanus L. & Sycamore & $12 \mathrm{w}$ at $1-5^{\circ} \mathrm{C}$ & 20 & $12-06$ \\
\hline Betula pendula Roth & Silver Birch & $\begin{array}{l}16 \mathrm{~h} \text { soak at } 4{ }^{\circ} \mathrm{C}, \\
\text { then spin dry }\end{array}$ & $0+$ sand $*$ & 09-07 \\
\hline Crataegus monogyna Jacq. & Hawthorn & $\begin{array}{l}8 \mathrm{w} \text { at } 15-20^{\circ} \mathrm{C}, \\
\text { then } 20 \mathrm{w} \text { at } 1-5^{\circ} \mathrm{C}\end{array}$ & 20 & $29-05$ \\
\hline Fraxinus excelsior $\mathrm{L}$. & Ash & $\begin{array}{l}16 \mathrm{w} \text { at } 15-20^{\circ} \mathrm{C} \text {, } \\
\text { then } 16 \mathrm{w} \text { at } 4^{\circ} \mathrm{C}\end{array}$ & 20 & $29-05$ \\
\hline Sorbus aucuparia L. & Rowan & $\begin{array}{l}2 \mathrm{w} \text { at } 15-20^{\circ} \mathrm{C}, \\
\text { then } 16 \mathrm{w} \text { at } 1-5^{\circ} \mathrm{C}\end{array}$ & 10 & $21-05$ \\
\hline
\end{tabular}

*Silver birch seed was sown on the surface and covered with sand.

Depth: sowing depth (mm); date: day-month; w: weeks.

this is most obvious above ground a number of studies have shown that below ground competition may be more important $[4,35]$. However, it is likely that the relative importance of each will vary depending on features such as the ages and sizes of competing species. Under competitive conditions plants suffer water stress and it is generally thought that below ground competition is mainly for water [24]. Below ground competition occurs via root systems and a variety of studies have shown gross changes in allocation of biomass between roots and shoots, and how the growth, size, spread and architecture etc., of tree root systems change in response to competition [1, 2, 6, 10, 13, 21, 27-29]. The morphology and growth rates of root systems differ considerably between species, but there have been few quantitative studies showing that these differences in rooting are important for competition between species [12]. Previous studies with tree seedlings have suggested that some of the competitive difference between species may be related to the adaptability of their root systems $[13,22,29]$. Data are sparse, but changes to allocation within the root system are likely to affect characters concerned with the utilisation of resources and space, such as specific root length, branching pattern and the number of root tips [11,29].

The following simple study was made primarily to investigate some of the changes that occur in the seedling root systems of 6 species of forest tree (Tab. I) when grown in competition with grass under nursery conditions, and secondarily whether these differences could be related to their ability to establish amongst a ground flora of competitive weeds. Seeds of two other species, Quercus robur L. and Corylus avellana L. were also pre-treated and sown but failed to germinate.

\section{MATERIALS AND METHODS}

Seeds of British provenances of the six tree species studied (Tab. I) were pre-treated prior to sowing in seed-beds in an open, experimental nursery in Southern England (Latitude $51^{\circ} 08^{\prime} \mathrm{N}$, Longitude $00^{\circ} 51^{\prime} \mathrm{W}$ ) during spring 2001. Pre-treatment conditions and periods for each species differed (Tab. I) and they were timed so that sowing of all species could take place simultaneously during April. Rows of seeds were sown $0.5 \mathrm{~m}$ apart in an unsterilised soil (a free- draining, sandy, humo-ferric podsol of loamy-sand texture) in 3 pairs of seed-beds approximately $1 \mathrm{~m}$ wide and raised approximately $10 \mathrm{~cm}$. Seeds were sown in single-species plots located randomly in each bed; within each plot there were 5 rows of seed. Individual plots were separated by $1 \mathrm{~m}$ buffer zones and interspecific competition between tree seedlings did not occur.

After sowing the tree seeds one bed of each pair was over-sown with grass seed $\left(20 \mathrm{gm}^{-2}\right.$, comprising $75 \%$ Festuca rubra ssp. rubra. $10 \%$ F. rubra ssp. commutata, 10\% Poa pratensis and 5\% Agrostis canina). The other beds were maintained weed-free by hand-pulling weeds at weekly or more frequent intervals. The seed-beds were protected by netting to exclude birds and small mammals, which were also trapped. The plots of silver birch were protected until mid-June with $50 \%$ shade netting to prevent scorching of the seed and seedlings. Beds were watered to field capacity using overhead sprinklers when soil moisture tension at a depth of about $15 \mathrm{~cm}$ fell below -15 centibars: in practice the plots were watered to run-off at least once every $48 \mathrm{~h}$ after the beginning of May. The grass was clipped once in early June to a height of about $10-15 \mathrm{~mm}$ to remove above-ground shade.

Sufficient viable seeds were sown in each row to give a minimum of 10 evenly distributed seedlings, the number varied between 20 and 200 viable seeds, depending on species. Emergence of seedlings was monitored every 2-4 days and for each species harvesting began when the number of seedlings present had stabilised. If necessary the number of tree seedlings in each row was reduced to ten by hand-thinning, maintaining as even a spacing as possible. One complete row was taken at random from the plot of each species in each bed at each harvest, these were at approximately weekly intervals beginning on the dates shown in Table I. A block of soil containing each seedling was excavated by hand, this was immediately immersed in a bucket of water to remove most of the soil. Further cleaning and separation of grass roots took place in a laboratory before the following assessments were made on all seedlings: height ( $\mathrm{mm}$, distance between root collar and shoot tip), length of tap root; number of 1st order lateral roots; root and shoot dry weights $\left(24 \mathrm{~h}, 95^{\circ} \mathrm{C}\right)$. Before drying further assessments were made on three randomly selected seedlings of each species/treatment combination: the length of the root system was measured with a $5 \mathrm{~mm}$ grid using the intersect method described by Tennant [31]; and the total number of root tips was counted. As the plants were small the whole of their root-systems were assessed. Plants generally had an obvious primary tap root but on the few plants where the primary root had died back the largest lateral root was defined as the tap root. 

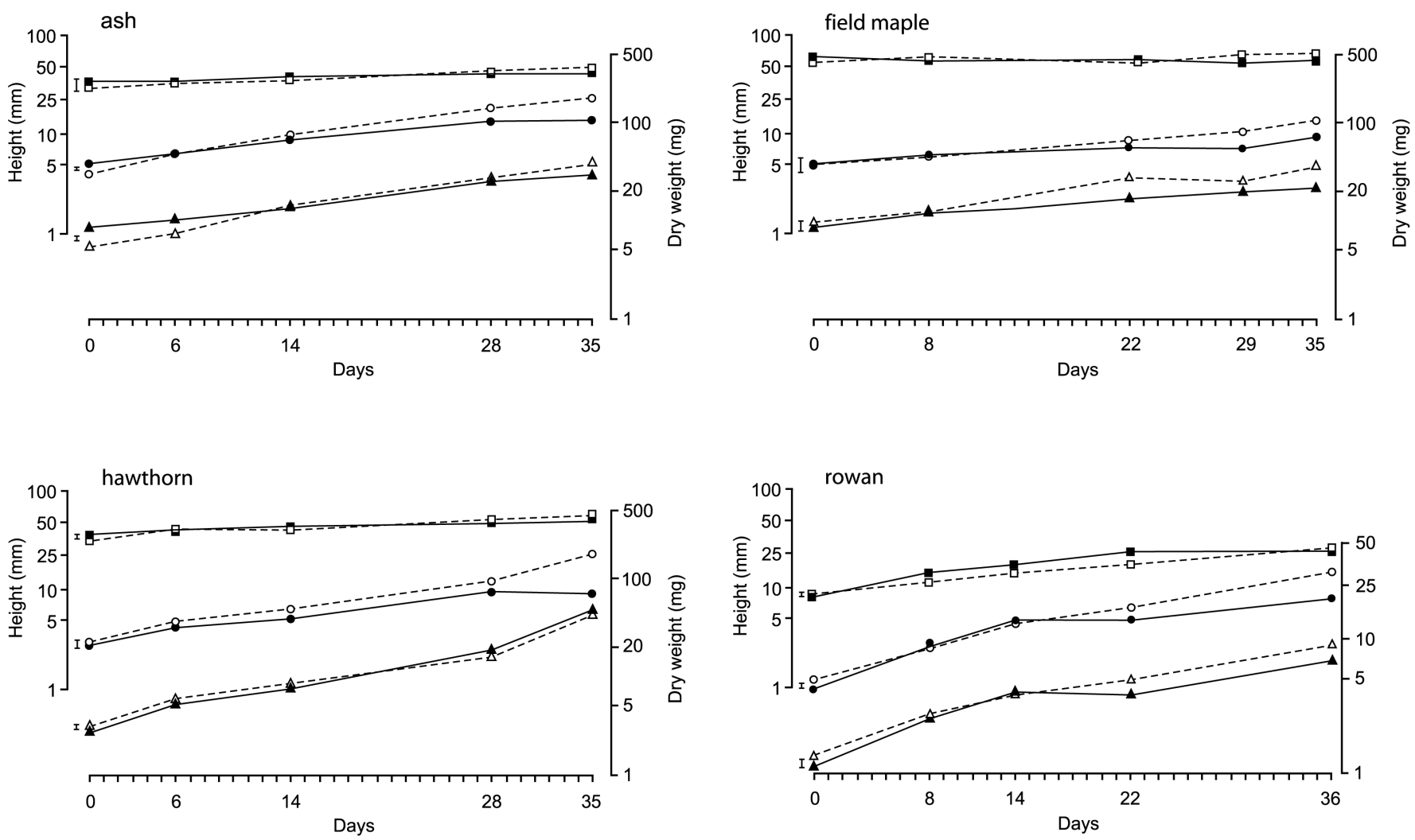

Figure 1. Size of plants at each harvest. Dashed lines and open symbols: without grass; solid lines and closed symbols: with grass; $\square$, $\mathbf{\square}$ : height; $\triangle, \boldsymbol{\Delta}$ : root weight; $\bigcirc, \boldsymbol{\bullet}$ : total weight. Standard errors of means for the grass $\times$ harvest interaction are also shown.

The experiment had three blocks of a split, split plot design, the main plots were with or without grass, and the sub-plots were the different harvests. The analyses were carried out on the sub-plot mean values for the replicate seedlings harvested at each date. Data for each species were analysed separately using Genstat [25]. Height and weights were transformed to natural logarithms and the data analysed using ANOVA, with 1 degree of freedom for the grass treatment and 4 for the harvest. The data for ash, field maple, hawthorn and rowan are plotted on logarithmic scale in Figure 1 which also shows the value of the standard error of the means for the grass $\times$ harvest interaction. Relative growth rates, root:shoot ratios, lengths of tap-root and total root system, and proportions were analysed using REML. The relationships between the number of first order lateral roots, length of lateral roots and taproot length, and the number of root tips and total root length were initially investigated using generalised linear models with untransformed counts, or linear regression using square root transformed data. Each analysis included data for all harvests of both grass treatments. The conclusions that could be drawn from these analyses were very similar with minor differences generally occurring in the levels of significance for the interactions between some of the terms in the models, however these accounted for small amounts of the variation relative to root lengths. For ease of presentation and interpretation, the data presented and described are for the simplest analyses with untransformed values investigated using multiple linear regression. Although data collected at each harvest were included in the models for each species only the fitted lines for the effect of grass treatments are presented in Figures 2 and 3, which also show the percentage of variation accounted for by the complete model.

\section{RESULTS}

The time interval between sowing and the emergence of seedlings and the date of the first harvest varied with species (Tab. I) with rowan being the first and silver birch the last. Grass seed had begun to germinate by 8th May. Despite sowing large numbers of viable seeds the germination of some species was poor and not all of the rows produced 10 seedlings; sycamore was the worst and only two harvests were possible within each block. Germination of silver birch occurred later than the other species and only a single harvest was possible. Excavation and preparation of plants generally caused little obvious damage to the root system with the exception of breakage and loss of the tip of the tap-root, this was always the youngest part of the root distal to the region with lateral roots. Whenever the broken parts were recovered they were always short and formed a very small proportion of each root.

The overall growth of ash, field maple, hawthorn and rowan is shown in Figure 1. Mean height generally increased for all species but was least noticeable for field maple. This may 

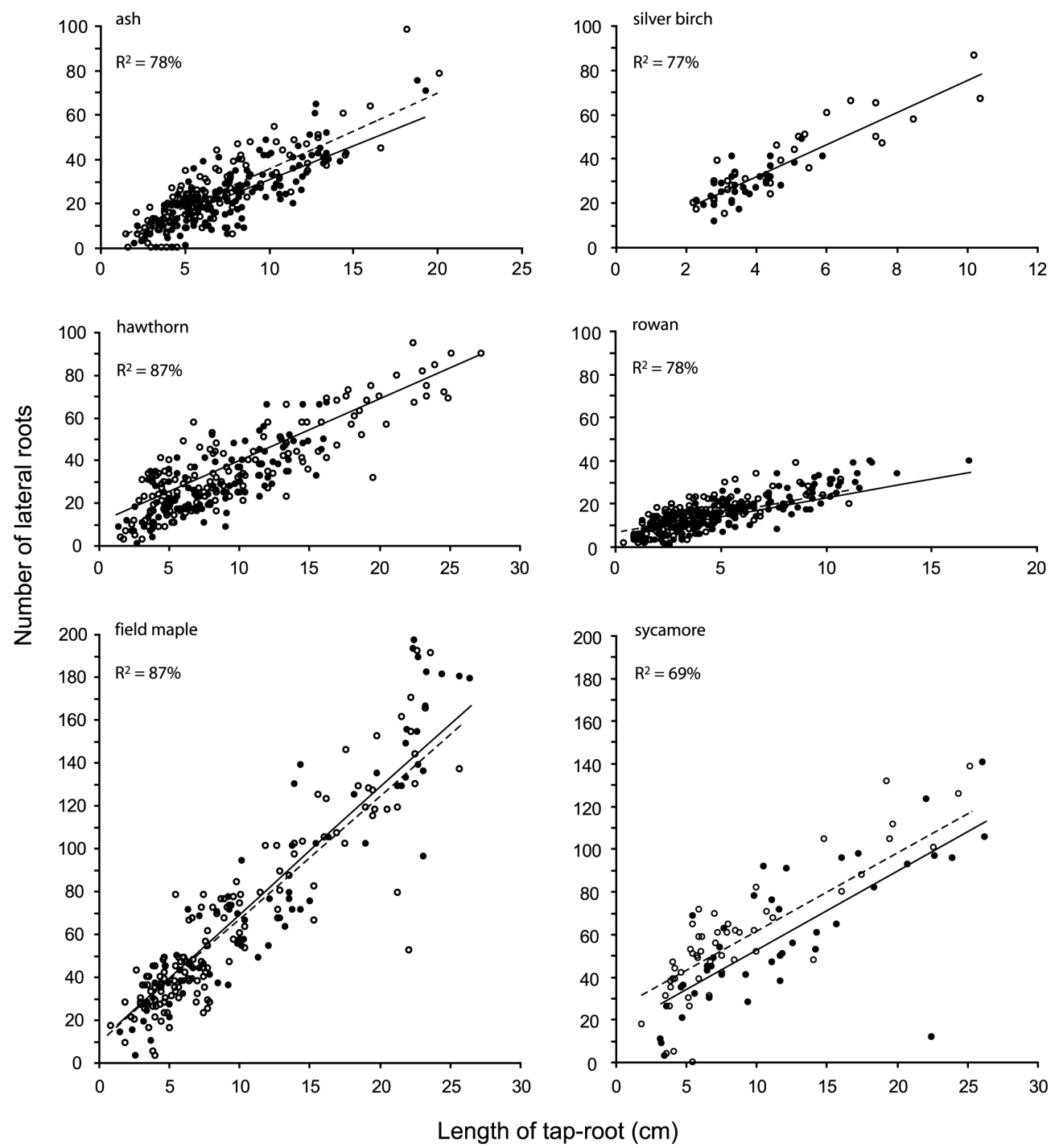

Figure 2. Number of 1st order lateral roots in relation to tap-root length -o-, with grass; - - O-- without grass. For species where only one line is shown then there was no significant difference between treatments. $\mathrm{R}^{2}$ : percentage of variation accounted for by the final model which included the data for all harvests.

reflect the differences in initial size of the seedling and the subsequent timing and pattern of shoot growth, with field maple producing a large seedling that did not begin extension growth of shoots as early as the other species with smaller seedlings. All four species showed significant increases in root and total weights, those of field maple being the largest and rowan the smallest (Fig. 1). Equivalent data for silver birch and the final harvest of sycamore are given in Table II. The effect of grass on height and weight varied between species and for some it was small. Although the presence of grass appeared to reduce the mean height in all species this was only significant for silver birch (Fig. 1 and Tab. II). Similarly the mean dry weight of roots was generally lower for the grass treatment but differences were never statistically significant. Grass significantly reduced the total dry weights of ash $(p \leq$ $0.05)$ silver birch $(p \leq 0.001)$ and hawthorn $(p \leq 0.001)$.

The relative growth rates of all species calculated for the intervals between harvests were very variable (data not shown) and although they generally declined during the experiment this was only significant for rowan $(p \leq 0.001)$. Overall the relative growth rates of seedlings in the treatments with grass were lower than those without grass but the differences were only significant for ash and hawthorn $(p \leq 0.05)$.

The allocation of dry matter to roots and shoots is illustrated by the mean root:shoot ratios shown in Table III. By the final harvest, for all species except field maple, those seedlings with grass had greater values for the root:shoot ratio than those without grass, but differences between means were only significant for ash. The root:shoot ratio for silver birch seedlings growing in grass was greater than one indicating that more dry matter had been allocated to roots than shoots. Overall there was a trend towards larger values at later harvests indicating that more dry matter was accumulating in the roots relative to the shoots, this harvest effect was significant for ash, field maple and hawthorn ( $p \leq 0.01$, data not shown).

The final length of the tap-roots were variable ranging from $0.25-26 \mathrm{~cm}$, mean values were least for silver birch and greatest for field maple. In the majority of species, grass competition increased tap-root length, but the only significant differences between treatments were for field maple and rowan 

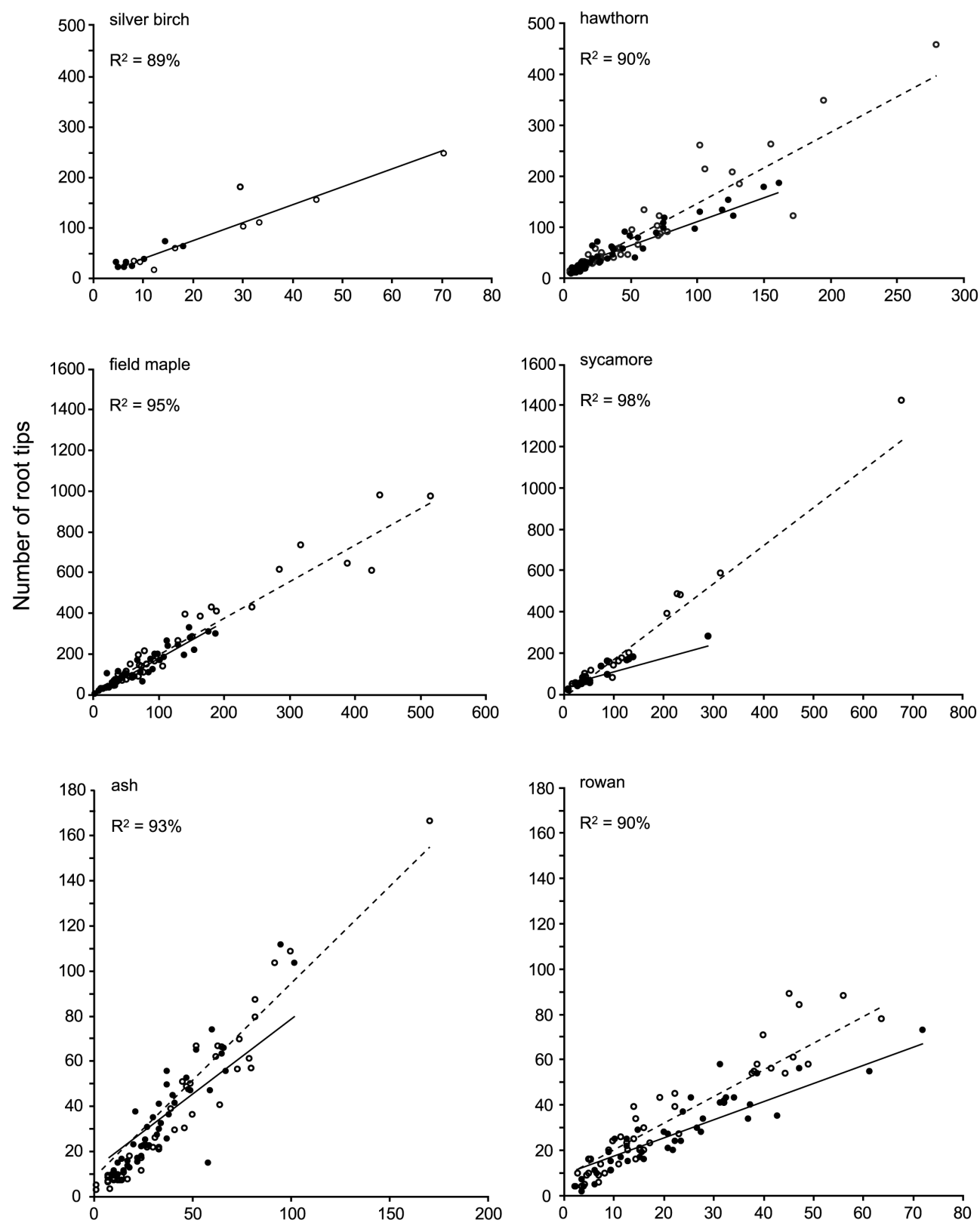

Total length of root $(\mathrm{cm})$

Figure 3. Number of root tips in relation to total root length. Symbols and other details as in Figure 2.

which increased by about $50 \%$. During the experiment there was no clear pattern in the differences between grass treatments in the total length of the root system. However, by the final harvest the mean length of the root system was shorter for all species in the grass treatment (Tab. III) with the $70 \%$ reduction for silver birch being statistically significant. The importance of the tap-root as a component of total root length was increased by the presence of grass. In all species the tap-root accounted for a greater proportion of total root length at the final harvest in the grass treatments (Tab. III) with silver birch and field maple having significant differences between means.
The specific root length at the final harvest was greater with grass for all species except sycamore indicating that in general competition increased the length of root produced relative to the biomass of the root system, but the effect of grass was only significant for ash.

There were significant, positive, linear relationships between the number of 1 st order lateral roots and the length of the tap-root for all species (Fig. 2). Over all species silver birch had the greatest, and rowan the fewest, number of lateral roots per unit length of tap-root. The effects of grass were generally small: it had no effect on the relationship between tap-root 
Table II. Mean values $\left(\log _{\mathrm{e}}\right)$ for height $(\mathrm{mm})$, and root and total dry weights (mg) of silver birch and sycamore at the final harvest.

\begin{tabular}{lccccc}
\hline & & \multicolumn{2}{c}{ Silver birch } & \multicolumn{2}{c}{ Sycamore } \\
\hline Height & $-\mathrm{G}$ & 2.59 & $p \leq 0.01$ & 4.42 & $\mathrm{NS}$ \\
& $+\mathrm{G}$ & 1.75 & $\mathrm{SE}=0.07$ & & $\mathrm{SE}=0.07$ \\
& $-\mathrm{G}$ & 0.82 & $\mathrm{NS}$ & 4.68 & $\mathrm{NS}$ \\
Root wt. & $+\mathrm{G}$ & -0.47 & $\mathrm{SE}=0.14$ & & $\mathrm{SE}=0.13$ \\
& $-\mathrm{G}$ & 2.01 & $p \leq 0.05$ & 5.95 & $\mathrm{NS}$ \\
Total wt. & & & $\mathrm{SE}=0.12$ & & $\mathrm{SE}=0.10$ \\
& $+\mathrm{G}$ & 0.29 & & 5.39 & \\
\hline
\end{tabular}

-G: without grass; +G: with grass; SE: standard error of means; NS: not significant. For Silver birch 30 plants were harvested from each grass treatment; for Sycamore there were 28 plants harvested in the $-\mathrm{G}$ and 20 in the $+\mathrm{G}$ treatments.

length and number of 1 st order lateral roots for hawthorn and silver birch; there was a small, constant difference between the two treatments for sycamore $(p \leq 0.001)$ and rowan $(p \leq$ 0.001 ) with those in the grass treatment having fewer laterals; and for ash and field maple there was some evidence of a reduction in number of laterals as the root length increased for the grass treatment (Fig. 2). Although this interaction between grass treatment and tap-root length for ash and field maple was statistically significant $(p \leq 0.05$ ) its effect on number of 1 st order laterals was small. For ash the main effect of grass $(p \leq$ 0.001 ) is more obvious (Fig. 2).
With the exception of silver birch the mean length of lateral root on a seedling was strongly related to the length of the taproot (all $p \leq 0.001$ ) and for all species was influenced by the grass treatment (data described below but not shown). For sycamore the grass treatments differed by a constant amount regardless of the tap-root's length, the seedlings with grass having significantly more lateral root $(p \leq 0.01)$ per unit length of tap-root. In contrast there was a significant interaction between grass treatment and length of the tap-root for the other four species. As the length of the tap-root increased the length of lateral root declined for ash $(p \leq 0.01)$ and field maple ( $p \leq 0.001$ ) seedlings grown with grass relative to those without grass. The converse was true for hawthorn and rowan where the relative amount of lateral root increased with taproot length in the with-grass treatment $(p \leq 0.01)$.

The relationships between root length and number of root tips are shown in Figure 3. There were significant positive relationships with length ( $p \leq 0.001$, except field maple $p \leq$ 0.01 ) for all species, and for silver birch the relationship was unaffected by the presence of grass. There was a small, constant difference between grass treatments for the relationship between tip numbers and root length for field maple $(p \leq 0.05$, Fig. 3), but for the remaining four species the number of root tips in the grass treatment declined relative to the withoutgrass treatment as root length increased ( $p \leq 0.01$ or lower). Silver birch produced the greatest number of root tips per unit root length regardless of treatment, whereas ash produced the fewest without grass and sycamore the fewest with grass.

Table III. Mean, minimum and maximum values for the lengths $(\mathrm{cm})$ of the tap-root and the total root system, and mean values for the ratio of root:shoot dry weights, the mean proportion of root length that is tap-root, and specific root length. All values are for the final harvest.

\begin{tabular}{|c|c|c|c|c|c|c|c|}
\hline & & No. & $\begin{array}{l}\text { Tap-root length } \\
(\mathrm{cm})\end{array}$ & $\begin{array}{c}* \text { Total root length } \\
(\mathrm{cm})\end{array}$ & $\mathrm{R}: \mathrm{S}$ & $\begin{array}{c}* \text { Proportion } \\
\text { of tap-root }\end{array}$ & $\begin{array}{c}* \text { Specific root } \\
\text { length }\end{array}$ \\
\hline Ash & $\begin{array}{l}-\mathrm{G} \\
+\mathrm{G}\end{array}$ & $\begin{array}{l}29 \\
29\end{array}$ & $\begin{array}{c}8.2(2.1-20.1) \\
\text { NS } \\
9.8(5.1-19.3)\end{array}$ & $\begin{array}{c}66.6(30.3-166.2) \\
\mathrm{NS} \\
63.1(14.9-111.6)\end{array}$ & $\begin{array}{c}0.300 \\
p \leq 0.01 \\
0.406\end{array}$ & $\begin{array}{l}0.122 \\
\mathrm{NS} \\
0.200\end{array}$ & $\begin{array}{c}1.57 \\
p \leq 0.05 \\
1.66\end{array}$ \\
\hline Silver Birch & $\begin{array}{l}-\mathrm{G} \\
+\mathrm{G}\end{array}$ & $\begin{array}{l}30 \\
30\end{array}$ & $\begin{array}{c}4.8(2.2-10.4) \\
\mathrm{NS} \\
3.7(2.3-5.9)\end{array}$ & $\begin{array}{c}28.3(8.3-70.3) \\
p \leq 0.05 \\
8.9(4.7-18.1)\end{array}$ & $\begin{array}{l}0.522 \\
\mathrm{NS} \\
1.06\end{array}$ & $\begin{array}{c}0.210 \\
p \leq 0.05 \\
0.494\end{array}$ & $\begin{array}{l}10.5 \\
\text { NS } \\
14.9\end{array}$ \\
\hline Field Maple & $\begin{array}{l}-\mathrm{G} \\
+\mathrm{G}\end{array}$ & $\begin{array}{l}30 \\
15\end{array}$ & $\begin{aligned} 11.2 & (0.5-25.7) \\
p & \leq 0.05 \\
16.5 & (4.5-26.4)\end{aligned}$ & $\begin{array}{c}222.7(2.1-516.5) \\
\text { NS } \\
120.1(39.3-176.4)\end{array}$ & $\begin{array}{l}0.472 \\
\text { NS } \\
0.444\end{array}$ & $\begin{array}{c}0.069 \\
p \leq 0.05 \\
0.141\end{array}$ & $\begin{array}{l}2.16 \\
\mathrm{NS} \\
2.85\end{array}$ \\
\hline Hawthorn & $\begin{array}{l}-\mathrm{G} \\
+\mathrm{G}\end{array}$ & $\begin{array}{l}28 \\
28\end{array}$ & $\begin{array}{c}13.9(3.2-23.0) \\
\mathrm{NS} \\
11.5(2.2-26.0)\end{array}$ & $\begin{array}{c}147.6(60.1-279.3) \\
\text { NS } \\
82.8(5.9-150.1)\end{array}$ & $\begin{array}{l}0.364 \\
\text { NS } \\
0.401\end{array}$ & $\begin{array}{l}0.109 \\
\text { NS } \\
0.146\end{array}$ & $\begin{array}{c}2.81 \\
\mathrm{NS} \\
3.88\end{array}$ \\
\hline Rowan & $\begin{array}{l}-\mathrm{G} \\
+\mathrm{G}\end{array}$ & $\begin{array}{l}29 \\
27\end{array}$ & $\begin{array}{c}5.6(2.4-11.1) \\
p \leq 0.05 \\
8.6(5.4-13.4)\end{array}$ & $\begin{array}{c}47.9(37.7-63.6) \\
\text { NS } \\
39.1(20.0-71.9)\end{array}$ & $\begin{array}{l}0.423 \\
\text { NS } \\
0.553\end{array}$ & $\begin{array}{c}0.137 \\
\mathrm{NS} \\
0.233\end{array}$ & $\begin{array}{l}3.99 \\
\mathrm{NS} \\
6.20\end{array}$ \\
\hline Sycamore & $\begin{array}{l}-\mathrm{G} \\
+\mathrm{G}\end{array}$ & $\begin{array}{l}28 \\
20\end{array}$ & $\begin{array}{c}11.2(3.9-25.2) \\
\mathrm{NS} \\
13.8(3.4-26.3)\end{array}$ & $\begin{array}{c}219.1(40.1-677.6) \\
\text { NS } \\
109.1(33.8-289.5)\end{array}$ & $\begin{array}{l}0.416 \\
\text { NS } \\
0.460\end{array}$ & $\begin{array}{l}0.061 \\
\text { NS } \\
0.154\end{array}$ & $\begin{array}{l}1.79 \\
\mathrm{NS} \\
1.32\end{array}$ \\
\hline
\end{tabular}

-G: without grass; +G: with grass; No.: total number of plants harvested from all blocks for each treatment, for characters marked with $*$ a random sample of nine plants was used in the analyses, see methods for further details; figures in brackets are minimum and maximum values; probability values for tap-root and total root system are those based on F-test following REML analysis after log transformation of data; NS: not significant. Specific root length: root length $(\mathrm{cm}) \div$ root wt. $(\mathrm{mg}) ; \mathrm{R}: \mathrm{S}$ : Root:shoot dry weight ratio. 


\section{DISCUSSION}

Although pre-treated seeds were sown the timing of emergence varied considerably between species with the harvesting period of each occurring at different stages of grass sward development. The data were collected by sequential harvesting and whilst this allows the observation of seedlings and root systems of different sizes it does not allow for the inevitable changes in the grass sward, or any ontogenetic drift in root development as the seedlings grow older or larger [20]. Weed biomass was not measured and it was assumed that systematic differences across the site were accounted for by the block structure of the experiment. However, it is possible that variation in weed biomass influenced seedling growth and development, especially as the species emerged at different times. As the differences in times of emergence were large in comparison to duration of the observations, and the state of the grass sward changed substantially during the experiment, direct statistical investigation of differences between all species is unwise. Any apparent differences between species should probably be regarded as indicative. The nursery used has freedraining, sandy soils and frequent irrigation is necessary to ensure survival of small, young seedlings, this may confound interpretation of the results as moisture is generally regarded as one of the most important factors involved in competition. Consequently, in common with many controlled experiments, direct extrapolation of these results to natural conditions is not possible. As with most studies of root systems the data were very variable and despite apparently large differences, means were often not significantly different.

In general the presence of grass caused an overall reduction in the stature of the seedlings, reducing height and dry weight but the differences were small and often not statistically significant. These are typical results that have been observed for a variety of tree and competing species [24]. The greatest reduction in total dry weight in competition with grass occurred for silver birch $(85 \%)$ with the biomass of other species being reduced by $20 \%$ or less. There are few comparative data relating directly to the species studied but Richardson [28] found that competition with Lolium perenne reduced total dry weight of sycamore by about $80 \%$. Overall the reductions found in the current study are small compared to those for other species reported elsewhere [8, 16-18, 26, 27], which may be related to the short, 5-6 week duration of the observations, rather than the several months, to one or more years, of the other studies.

Many studies have shown that changes occur in the allocation of biomass to roots and shoot in response to water or nutrient stress, typically a greater proportion of biomass will be allocated to roots than shoots [24]. Similar changes are seen when tree seedlings grow in competition with other vegetation $[5,16-18,28]$ although this may not always occur [8, 27]. It is generally assumed that the adverse effects of competition on seedling tree growth are due to increased competition for moisture but this is not always true, for example Collet et al., [8] found that negative effect of grasses on Quercus petraea seedlings were independent of competition for water. A similar result was found for Juglans regia [27]. The seed beds used in the experiments described were fertile and regularly watered, occasional measurements showed little differences in the percentage moisture content of soil but the occurrence of some drought events cannot be excluded. Competition with grass tended to increase the root:shoot ratio of the six species studied in this experiment and although the increase was not significant for most of these, it is a response reported elsewhere. Larger seedlings tend to have greater root:shoot ratios [20] suggesting that size may have some influence on the effects of grass treatment and the general increase in root:ratio during the experiment. Although grass can cause changes in the relative amount of biomass allocated to roots and shoots it is not clear if the effects are the same for all species and how they may change with time.

Following a study of competition between Acer pseudoplatanus and Lolium perenne Richardson [28] suggested that competition with grass modifies not only the size of the tree's root system, but also its form, and rate and pattern of growth. Similar results have been reported for Prunus avium [10]. Overall the results on root structure found in this experiment are consistent with this conclusion, but the magnitude and significance of the effects varied with species. The presence of grass tended to increase the length of tap-root, reduce the total length of the root system, increase the proportion of the root length that was tap-root, and increase specific root length, but for most species the effect was not significant. Overall there were small changes in the relationship between the number of 1 st order lateral roots and tap-root length, in contrast for most species the number of root tips per unit length of root declined in the presence of grass, suggesting that branching of lateral roots may be reduced. In general, as reported elsewhere [27, 28], competition with grass appeared to reduce the development and spread of the lateral root system, but as the species differences in this study indicate other results may be found. For example, despite seven seasons of reduced competition from grass by use of an organic mulch, only one of seven hardwood species showed a significant increase in fine root density in the top $7.5 \mathrm{~cm}$ of soil [32]. Also observations of apple trees during the summer found that there were generally more long (extension) roots and short (lateral) roots in areas under grass than in vegetation free plots, and that new growth was similarly greater [1]. Although the large scale structures of tree root systems have been described following excavation and observation in the field $[19,30]$ there have been few comparative experiments observing differences at the small scale which, included those species used in the investigation described. After a small study of ash and sycamore seedlings growing in the field and under nursery conditions, Majid [22] suggested that sycamore seedlings had root systems that were less adaptable than ash which may result in greater mortality in competitive situations. In a study comparing four species, Harmer [13] found that the adverse effect of grass was greater for sycamore than ash. The difference between these two species was less clear in the current experiment.

Overall the influence of the developing grass sward on the gross size of the young, recently germinated tree seedlings was small, and it had some variable effects on the distribution of dry matter between seedlings' roots and shoots, and the development of the root system. Some of these differences can be related to the changes that would be expected due to competition. However, species differences cannot properly be tested and it is difficult to identify characteristics of the root systems 
that may be associated with their relative ability to establish in the field. For example the total root length of silver birch was reduced by the greatest proportion when in competition with grass, whilst this is consistent with its well-known inability to establish in dense swards, it germinated last and at a time when the experimental sward was better developed and presumably more competitive than for the other species. In contrast ash seedlings, which also perform badly in competition with grass, suffered little reduction in total root length. Hawthorn, a species that will establish in a grass sward had characteristics that were not consistently different from other less able species. From the data collected it is difficult to support the suggestion that differences in the root characteristics between species are related in a simple way to their ability to establish in a ground flora of competitive weeds. In any further comparative studies it may be necessary to include observation of physiological factors such as nutrition, water relations and photosynthesis.

Acknowledgements: Corrine Baker for providing pre-treated seed. The staff at Headley nursery for establishing and maintaining the experiment. Roger Boswell for assistance with statistical analyses.

\section{REFERENCES}

[1] Atkinson D., The growth, activity and distribution of the fruit tree root system, Plant Soil 71 (1983) 23-35

[2] Bauhus J., Messier C., Soil exploitation strategies of fine roots in different tree species of the southern boreal forest of eastern Canada, Can. J. For. Res. 29 (1999) 260-273.

[3] Burton P.J., Bazzaz F.A., Ecophysiological responses of tree seedlings invading different patches of old-field vegetation, J. Ecol. 83 (1995) 99-112.

[4] Caldwell M.M., Competition between root systems in natural communities, in: Gregory P.J., Lake J.V., Rose D.A. (Eds.), Root development and function, Cambridge University Press, Cambridge, 1987, pp. 267-185.

[5] Cogliastro A., Gagnon D., Bouchard A., Effet des sites et des traitements sylvicoles sur la croissance, l'allocation en biomasse et l'utilisation de l'azote de semis de quatre espèces feuillues en plantations dans le sud-ouest du Québec, Can. J. For. Res. 23 (1993) 199-209.

[6] Coker E.G., Root development of apple trees in grass and clean cultivation, J. Hort. Sci. 34 (1959) 111-121.

[7] Coll L., Balandier P., Picon-Cochard C., Prévosto B., Competition for water between beech seedlings and surrounding vegetation in different light and vegetation composition conditions, Ann. For. Sci. 60 (2003) 593-600.

[8] Collet C., Guehl J.-M., Frochot H., Ferhi A., Effect of two forest grasses differing in their growth dynamics on the water relations and the growth of Quercus petraea seedlings, Can. J. Bot. 74 (1996) $1562-1571$.

[9] Davies R.J., Trees and Weeds, Forestry Commission Handbook 2, HMSO, London, 1987.

[10] Dawson L.A., Duff E.I., Campbell C.D., Hirst D.J., Depth distribution of cherry (Prunus avium L.) tree roots as influenced by grass root competition, Plant Soil 231 (2001) 11-19.

[11] Fitter A.H., Functional significance of root morphology and root system architecture, in: Fitter A.H. (Ed.), Ecological interactions in soil: plants, microbes and animals, Blackwell Scientific Publications, Oxford, 1985, pp. 87-106.

[12] Gregory P.J., Development and growth of root systems in plant communities, in: Gregory P.J., Lake J.V., Rose D.A. (Eds.), Root development and function, Cambridge University Press, Cambridge, 1987 pp. $147-166$

[13] Harmer R., Growth of seedling tree root-systems in competition with grasses, Asp. Appl. Biol. 44 (1996) 47-54.

[14] Harmer R., Kerr G., Boswell R., Characteristics of lowland broadleaved woodland being restocked by natural regeneration, Forestry 70 (1997) 199-210.

[15] Hodge S.J., Harmer R., Woody colonization on unmanaged urban and ex-industrial sites, Forestry 69 (1996) 245-261.

[16] Holl K.D., Effects of above- and below-ground competition of shrubs and grass on Calophyllum brasiliense (Camb.) seedling growth in abandoned tropical pasture, For. Ecol. Manage. 109 (1998) 187-195.

[17] Kolb T.E., Steiner K.C., Growth and biomass partitioning of northern red oak and yellow-poplar seedlings: effects of shading and grass root competition, For. Sci. 36 (1990) 33-44.

[18] Kolb T.E., Steiner K.C., Growth and biomass partitioning response of northern red oak genotypes to shading and grass root competition, For. Sci. 36 (1990) 293-303.

[19] Köstler J.N., Brückner E., Biebelriether H., Die Wurzeln der Waldbäume, Paul Parey, Hamburg, 1968.

[20] Ledig F.T., The influence of genotype and environment on dry matter distribution in plants, in: Huxley P.A. (Ed.), Plant research and agroforestry, International Council for Research in Agroforestry, Nairobi, 1983, pp. 427-453.

[21] Ludovici K.H., Morris L.A., Competition-induced reductions in soil water availability reduced fine root extension rates, Soil Sci. Soc. Am. J. 61 (1997) 1196-1202.

[22] Majid A., Root systems of ash and sycamore seedlings, J. Oxf. Univ. For. Soc. 4 (1954) 18-21.

[23] Myster R.W., Tree invasion and establishment in old fields at Hutcheson Memorial Forest, Bot. Rev. 59 (1993) 251-272.

[24] Nambiar E.K.S., Sands R., Competition for water and nutrients in forests, Can. J. For. Res. 23 (1993) 1955-1968.

[25] Payne R.W., Lane P.W., Digby P.G.N., Harding S.A., Leech P.K., Morgan G.W., Todd A.D., Thompson R., Tunnicliffe Wilson G. Welham S.J., White R.P., Genstat 5 Release 3 Reference Manual, Oxford University Press, Oxford, 1993.

[26] Peer H., Experimentelle Untersuchungen zur Konkurrenzkraft von Forstunkräutern auf Fichten, Forstw. Cbl. 95 (1976) 149-165.

[27] Picon-Cochard C., Nsourou-Obame A., Collet C., Guehl J.-M., Ferhi A., Competition for water between walnut seedlings (Juglans regia) and rye grass (Lolium perenne) assessed by carbon isotope discrimination and $\delta^{18} 0$ enrichment, Tree Physiol. 21 (2001) 183191

[28] Richardson S.D., Root growth of Acer pseudoplatanus L. in relation to grass cover and nitrogen deficiency, Meded. Landb. Hoogesch. Wageningen 53 (1953) 75-97.

[29] Rust S., Savill P.S., The root systems of Fraxinus excelsior and Fagus sylvatica and their competitive relationships, Forestry 73 (2000) 499-508.

[30] Stone E., Kalisz. P.J., On the maximum extent of tree roots, For. Ecol. Manage. 46 (1991) 59-102.

[31] Tennant D., A test of a modified line intersect method of estimating root length, J. Ecol. 63 (1975) 995-1001.

[32] Watson G.W., Organic mulch and grass competition influence tree root development, J. Arboric 14 (1988) 200-203.

[33] Williamson D.R., Establishing farm woodlands, Forestry Commission Handbook 8, HMSO, London, 1992.

[34] Willoughby I., Dewar J., The use of herbicides in the forest, Forestry Commission Field Book 8, HMSO, London, 1995.

[35] Wilson J.B., Shoot competition and root competition, J. Appl. Ecol. 25 (1988) 279-296 